\title{
PENGARUH INTELLIGENCE QUOTIENT, EMOTIONAL QUOTIENT, SPIRITUAL QUOTIENT, DAN SELF EFFICACY TERHADAP KINERJA AUDITOR ( Studi Empiris Pada Beberapa Kantor Akuntan Publik Di Jakarta Selatan )
}

\author{
Jahormin Simarmata \\ dan \\ Nursamsiyah \\ Universitas Satya Negara Indonesia \\ Email: jahormin.simarmata@gmail.com \& nursamsiyayah@gmail.com
}

\begin{abstract}
ABSTRAK
Tujuan dari penelitian ini adalah untuk mengetahui; pengaruh Kecerdasan Intelektual, Kecerdasan Emosional, Kecerdasan Spiritual, dan Kepercayaan Diri terhadap Kinerja Auditor secara parsial dan simultan.

Metode yang digunakan dalam penelitian ini adalah metode Purposive Sampling dengan jumlah sampel yang diperoleh sebanyak 94. Pengolahan data menggunakan program SPSS versi 21.0. Populasi dan sampel dalam penelitian ini adalah auditor pada Kantor Akuntan Publik di Wilayah Jakarta Selatan. Data yang digunakan dikategorikan sebagai data primer. Data dikumpulkan melalui penyebaran kuesioner.

Secara parsial Kecerdasan Intelektual dan Kepercayaan Diri berpengaruh positif terhadap Kinerja Auditor, sedangkan Kecerdasan Emosional, dan Kecerdasan Spiritual tidak berpengaruh terhadap kinerja auditor. Secara simultan hasil penelitian ini menunjukkan bahwa Kecerdasan Intelektual, Kecerdasan Emosional,Kecerdasan Spiritual, dan Kepercayaan Diri berpengaruh positif signifikan terhadap kinerja auditor sebesar $46,3 \%$. Sedangkan sisanya yaitu sebesar $53,7 \%$ dipengaruhi oleh variabel-variabel lain yang tidak termasuk dalam penelitian ini.
\end{abstract}

Kata Kunci : Kecerdasan Intelektual, Kecerdasan Emosional, Kecerdasan Spiritual, Kepercayaan Diri dan Kinerja Auditor.

\begin{abstract}
The aim of this research is to identify the influence of Intelligence Quoetient, Emotional Quoetient, Spiritual Quoetient and Self Efficacy on partial and simultaneous to the Auditor Performance.

The method used in this research is Purposive Sampling method with the number of samples obtained was 94 samples. The data processed using SPSS version 21.0. Population and sample in this research are the Auditors who works at Public Accounting Firm in South Jakarta. The data used in this research is categorized as primary data. The data were collected through questionnaires.

Partially, Intelligence Quoetient and Self Efficacy have a positive effect on Auditor Performance, while Emotional Quoetient and Spiritual Quoetient have no effect on Auditor Performance. Simultaneously the results of this research indicates that Intelligence Quoetient, Emotional Quoetient, Spiritual Quotient,and Self Efficacy have positive effect as on the Auditor Performance $46.3 \%$. While $53.7 \%$ influenced by the other variables which are not included in this research.
\end{abstract}

Keywords: Intelligence Quoetient, Emotional Quoetient, Spiritual Quoetient, Self Efficacy and Auditor Performance. 


\section{PENDAHULUAN}

\section{Latar Belakang Penelitian}

Kantor akuntan publik merupakan sebuah organisasi yang bergerak di bidang jasa. Jasa yang diberikan berupa jasa audit operasional, audit kepatuhan (compliance audit) dan audit laporan keuangan (Arens dan Loebbecke 2011). Profesi akuntan publik bertanggung jawab atas kepercayaan masyarakat berupa tanggung jawab moral dan tanggung jawab professional, melalui asosiasi profesi berdasarkan standar profesi yang dikeluarkan oleh Ikatan Akuntan Indonesia.

Akuntan publik memiliki peranan penting di masyarakat, terutama dalam hal meningkatkan kredibilitas dan kualitas laporan keuangan suatu entititas. Sehingga pihak pemakai informasi kreditur dan investor akan sangat dipengaruhi oleh akuntan publik sebelum mereka mengambil keputusan atau memberikan kepercayaan mereka (Widyastary dkk., 2014)

Kinerja auditor tidak hanya dilihat dari kemampuan kerja yang sempurna, tetapi juga kemampuan menguasai dan mengelola diri sendiri serta kemampuan dalam membina hubungan dengan orang lain (Martin 2000,dalam Fabiola 2005). Akuntan yang cerdas secara intelektual belum tentu dapat memberikan kinerja yamg optimal terhadap organisasi dalam bekerja, namun juga cerdas secara emosional dan spiritual tentunya akan menampilkan kinerja yang lebih optimal untuk Kantor Akuntan Publik dimana mereka bekerja.

Kecerdasan intelektual dulunya diyakini dapat menentukan kesuksesan seseorang, semakin tinggi kecerdasan intelektual seseorang maka akan semakin sukseslah orang tersebut. Namun seiring berjalannya waktu, kecerdasan intelektual bukanlah satu-satunya hal yang dapat menentukan kesuksesan. Seorang auditor yang memiliki kecakapan emosional mampu mengetahui dan menangani perasaan mereka sendiri dengan baik dan mampu membaca serta menghadapi perasaan orang lain dengan efektif. Kecerdasan spiritual memungkinkan manusia untuk berpikir kreatif, berwawasan jauh, membuat atau bahkan mengubah aturan, yang membuat orang tersebut dapat bekerja lebih baik. Spiritual Quoetient/Kecerdasan Spiritual merupakan landasan yang diperlukan untuk memfungsikan Intelligence Quoetient/Kecerdasan Intelektual dan Emotional Quoetient/Kecerdasan Emosional secara efektif. Secara singkat kecerdasan spiritual mampu mengintegrasikan dua kemampuan lain yang sebelumnya telah disebutkan yaitu kecerdasan intelektual dan kecerdasan emosional (Idrus 2002).

Untuk menghasilkan kinerja yang baik tidak hanya melihat kesempurnaan dalam kemampuan bekerja, namun melihat juga kemampuan yang dimiliki oleh setiap individu. Kemampuan tersebut berupa kecerdasan, yaitu kecerdasan intelektual, kecerdasan emosional, dan kecerdasan spiritual (Wijayanti, 2012 dalam Chandra dan Ramantha, 2013).

Berdasarkan penelitian sebelumnya yang melatarbelakangi penelitian ini yaitu penelitian yang dilakukan oleh Kristiyanti (2015) mengenai pengaruh emotional quotient dan self efficacy terhadap kinerja auditor dengan Studi Kasus Kantor Akuntan di Surakarta dan Yogyakarta terdapat pengaruh yang positif dan signifikan terhadap kinerja auditor. Dengan demikian peneliti ingin menguji kembali kedua variabel tersebut apakah akan mendapatkan hasil yang sama apabila penulis menambahkan variabel lain, waktu serta tempat penelitian yang berbeda. 
Dari uraian tersebut, penelitian ini dilakukan untuk mengetahui kembali pengaruh Intelligence Quoetient (IQ)/Kecerdasan Intelektual , Emotional Quoetient (EQ)/Kecerdasan Emosional, Spiritual Quoetient (SQ)/Kecerdasan Spiritual dan Self Efficacy/Kepercayaan Diri berpengaruh terhadap kinerja auditor baik secara parsial maupun simultan dengan tempat penelitian pada Kantor Akuntan Publik di Wilayah Jakarta Selatan yang bersedia menerima peneliti.

\section{LANDASAN TEORI}

\section{Pengertian Auditing}

Auditing merupakan salah satu atestasi. yakni suatu komunikasi dari seorang expert mengenai kesimpulan tentang realibilitas dari pernyataan seseorang. Berikut ini beberapa pengertian Auditing menurut para ahli, yaitu sebagai berikut: Menurut ASOBAC ( $A$ Statement of Basic Auditing Concept) dalam Abdul Halim (2008:1) definisi audit adalah Abdul Halim (2008:1) definisi audit adalah suatu proses sistematis untuk menghimpun dan mengevaluasi bukti-bukti secara obyektif mengenai asersi-asersi tentang berbagai tindakan dan kejadian ekonomi untuk menentukan tingkat kesesuaian antara asersi-asersi tersebut dengan kriteria yang telah ditentukan dan menyampaikan hasilnya kepada para pemakai yang berkepentingan. Sukrisno Agoes $(2016$; 4) menyatakan bahwa Audit adalah suatu pemeriksaan yang dilakukan secara kritis dan sistematis, oleh pihak yang independen, terhadap laporan keuangan yang telah disusun oleh manajemen, beserta catatan-catatan pembukuan dan bukti-bukti pendukungnya, dengan tujuan untuk dapat memberikan pendapat mengenai kewajaran laporan keuangan tersebut.

\section{Standar Auditing}

Menurut Webster's New International Dictionary dalam Mulyadi (2014:16-17), Standar auditing adalah suatu ukuran pelaksanan tindakan yang merupakan pedoman umum bagi auditor dalam melaksanakan audit. Standar auditing yang ditetapkan oleh Ikatan Akuntan Indonesia dalam Pernyataan Standar Akuntansi No. 01 (SA Seksi $150^{2}$ ), terdiri dari sepuluh standar auditing dan dibagi menjadi tiga kelompok, sebagai berikut:

Standar Umum ; berkaitan dengan persyaratan auditor dan mutu pekerjaannya sehingga bersifat pribadi. Standar ini mencakup tiga bagian, yakni:

1. Audit harus dilaksanakan oleh seorang atau lebih yang memiliki keahlian dan pelatihan teknis yang cukup sebagai auditor.

2. Dalam semua hal yang berhubungan dengan perikatan, independensi dalam sikap mental harus dipertahankan oleh auditor.

3. Dalam pelaksanaan audit dan penyusunan laporannya, auditor wajib menggunakan kemahiran profesionalnya dengan cermat dan seksama.

Standar pekerjaan lapangan ; berisi tentang sikap dan pengetahuan yang wajib dimiliki seorang akuntan publik (auditor). Standar ini terdiri dari 3 poin, yakni:

1. Pekerjaan harus direncanakan sebaik-baiknya dan jika digunakan asisten harus disupervisi dengan semestinya.

2. Pemahaman memadai atas pengendalian intern harus diperoleh untuk merencanakan audit dan menentukan sifat, saat, dan lingkup pengujian yang akan dilakukan.

3. Bukti audit kompeten yang cukup harus diperoleh melalui inspeksi, pengamatan, permintaan keterangan, dan konfirmasi sebagai dasar memadai untuk menyatakan pendapat atas laporan keuangan yang diaudit. 
Standar pelaporan terdiri dari empat poin yakni:

1. Laporan auditor harus menyatakan apakah laporan keuangan telah disusun sesuai dengan prinsip akuntansi yang berlaku umum di Indonesia.

2. Laporan auditor harus menunjukkan atau menyatakan, jika ada, ketidakkonsistenan, penerapan prinsip akuntansi dalam penyusunan laporan keuangan periode berjalan dibandingkan dengan penerapan prinsip akuntansi tersebut dalam periode sebelumnya.

3. Pengungkapan informatif dalam laporan keuangan harus dipandang memadai, kecuali dinyatakan lain dalam laporan auditor.

4. Laporan auditor harus memuat suatu pernyataan pendapat mengenai laporan keuangan secara keseluruhan atau suatu asersi bahwa pernyataan demikian tidak dapat diberikan, maka alasannya harus dinyatakan.

\section{Definisi Auditor}

Auditor adalah seseorang yang memiliki kualifikasi tertentu dalam melakukan audit atas laporan keuangan dan kegiatan suatu perusahaan atau organisasi. Menurut Peraturan Menteri Keuangan No: 17/PMK.01/2008 tentang jasa akuntan publik menyebutkan bahwa akuntan adalah seseorang yang berhak menyandang gelar atau sebutan akuntan sesuai dengan peraturan perundang-undangan yang berlaku. Auditor harus telah menjalani pendidikan dan pelatihan teknis yang cukup dalam praktik akuntansi dan teknik auditing (Mulyadi, 2014:25). Ketentuan tentang jasa akuntan publik tersebut telah ditegaskan kemudian dengan UndangUndang Republik Indonesia No. 5 tahun 2011 tentang Akuntan Publik.

\section{Kantor Akuntan Publik}

Menurut Peraturan Menteri Keuangan No. 17/PMK.01/2008 tentang jasa akuntan publik dan telah ditegaskan kemudian dengan keputusan Undang-Undang No. 5 tahun 2011 tentang Akuntan Publik, menyatakan bahwa Kantor Akuntan Publik adalah badan usaha yang telah mendapatkan izin dari Menteri sebagai wadah bagi Akuntan Publik dalam memberikan jasanya. "Hak untuk melakukan audit diberikan kepada kantor akuntan publik oleh peraturan di setiap Negara bagian" (Arens et.al, 2011:34).

Kantor akuntan publik bertanggungjawab mengaudit laporan keuangan historis yang dipublikasikan oleh semua perusahaan terbuka, kebanyakan perusahaan lain yang cukup besar dan banyak perusahaan serta organisasi non-komersial yang lebih kecil. Sebutan kantor akuntan publik mencerminkan fakta bahwa auditor yang menyatakan pendapat audit atas laporan keuangan harus memiliki lisensi sebagai akuntan publik (Arens et,al, 2011:19). KAP juga harus dievaluasi secara rutin (peer review) yaitu suatu telaah, oleh akuntan publik, atas ketaatan KAP pada sistem pengendalian mutu kantor itu sendiri sebagaimana disyaratkan dalam Pernyataan Standar Audit No. 20 / PSPM No. 01 yang ditetapakan oleh Ikatan Akuntan Publik Indonesia.

\section{Kinerja Auditor}

Kinerja berasal dari kata prestasi kerja (performance). Sebagaimana dikemukakan oleh Mangkunegara (2013:67) bahwa istilah kinerja berasal dari kata job performance atau actual performance (prestasi kerja atau prestasi sesungguhnya yang dicapai seseoorang) yaitu hasil kerja secara kualitas dan kuantitas yang dicapai oleh seorang pegawai dalam melaksanakan tugasnya sesuai dengan tanggungjawab yang diberikan kepadanya. Mangkunegara (2013:67) menyatakan bahwa Kinerja adalah hasil kerja yang secara kualitas dan kuantitas yang dicapai oleh seorang pegawai dalam melaksanakan tanggungjawab yang diberikan padanya. Gibson et, al 1996 (dalam Nurul Arifah, 2012) mengemukakan bahwa Kinerja adalah suatu ukuran 
yang dapat digunakan untuk menetapkan perbandingan hasil pelaksanaan tugas, tanggungjawab yang diberikan oleh organisasi pada periode tertentu dan relatif dapat digunakan untuk mengukur prestasi kerja atau kinerja organisasi. Sementara Kalbers dan Forgatty, 1995 (dalam Trisnaningsih, 2004) mengatakan bahwa Kinerja auditor sebagai evaluasi terhadap pekerjaan yang dilakukan oleh atasan, rekan, diri sendiri, dan bawahan langsung.

Dimensi kinerja merupakan ukuran dan penilaian dari perilaku yang aktual di tempat kerja, mencakup :

1. Kualitas; Kinerja seseorang dinyatakan baik apabila kualitas output yang dihasilkan lebih baik atau sama dengan target yang ditentukan.

2. Kuantitas; Kinerja seseorang diukur dari jumlah output yang dihasilkan.

3. Ketepatan waktu; Ketepatan waktu juga menjadi pertimbangan dalam mengukur kinerja seseorang tanpa mengabaikan kualitas atau kuantitas output yang dicapai.

4. Kooperatif; Kinerja dinilai dari kemampuan individu untuk tetap bersikap kooperatif dengan pekerja lain dan juga harus menyelesaikan tugas masing-masing.

5. Komitmen; Kemauan atau kemampuan seseorang untuk dapat menyeimbangkan antara sikap dan tindakan untuk mewujudkan tujuan organisasi dengan mengutamakan kepentingan organisasi dari pada kepentingan diri sendiri.

\section{Intelligence Quotient (IQ)/ Kecerdasan Intelektual}

Kecerdasan intelektual lazim disebut dengan inteligensi. Istilah ini dipopulerkan kembali pertama kali oleh Francis Galton, seorang ilmuwan dan ahli matematika yang terkemuka dari Inggris (Joseph, 1978:19) dalam Fabiola (2005), inteligensi adalah kemampuan kognitif yang dimiliki organisme untuk menyesuaikan diri secara efektif pada lingkungan yang kompleks dan selalu berubah serta dipengaruhi oleh faktor genetik (Galton, dalam Fabiola 2005).

Kecerdasan intelektual menurut Stenberg dalam Choiriah (2013) adalah sebagai kemampuan untuk belajar dari pengalaman, berfikir untuk menggunakan proses-proses metakognitif, dan kemampuan untuk beradaptasi dengan lingkungan sekitar.

Berdasarkan hubungan beberapa pengertian di atas, dapat disimpulkan bahwa kecerdasan intelektual adalah kemampuan seseorang untuk memperoleh pengetahuan, kemampuan untuk belajar dari pengalaman, menguasai serta dapat menerapkan dalam menghadapi atau memecahkan masalah.

Stenberg dalam Choiriah (2013) menyebutkan bahwa kecerdasan intelektual memiliki indikator sebagai berikut:

1. Kemampuan memecahkan masalah; yaitu mampu menunjukkan pengetahuan mengenai masalah yang dihadapi, mengambil keputusan tepat, menyelesaikan masalah secara optimal, menunjukkan fikiran jernih.

2. Intelegensi verbal ; yaitu kosa kata baik, membaca dengan penuh pemahaman ingin tahu secara intelektual, menunjukkan keingintahuan.

3. Intelegensi prakis ; yaitu situasi, tahu cara mencapai tujuan, sadar terhadap dunia sekeliling, menunjukkan minat terhadap dunia luar.

\section{Emotional Quotient (EQ)/Kecerdasan Emosional}

Kamus Besar Bahasa Indonesia, mendefinisikan emosi sebagai luapan perasaan yang berkembang dan surut dalam waktu singkat serta keadaan dan reaksi psikologi dan fisiologis seperti kegembiraan, kesedihan, keharuan, dan kecintaan. Menurut Ary $(2015 ; 56)$, mengatakan bahwa perusahaan-perusahaan raksasa dunia menyimpulkan bahwa inti kemampuan pribadi dan sosial yang merupakan kunci utama keberhasilan seseorang adalah 
kecerdasan emosional. Kecerdasan emosional sangat dipengaruhi oleh lingkungan, tidak bersifat menetap, dapat berubah-ubah setiap saat..

Deskripsi kecerdasan emosional sudah ada sejak dikenalnya perilaku manusia. Berdasarkan penjelasan di atas, terdapat pula penjelasan dari beberapa para ahli mengenai kecerdasan emosional sebagai berikut:

1. Daniel Goleman (2015), Emotional Quotient (EQ)/kecerdasan emosional adalah kemampuan untuk memotivasi diri sendiri dan bertahan menghadapi frustasi; mengendalikan dorongan hati dan tidak melebih-lebihkan kesenangan; mengatur suasana hati dan menjaga agar beban stress tidak melumpuhkan kemampuan berpikir; berempati dan berdoa.

2. Salovely dan Mayer 1990 (dalam Dhani Pradipta 2015), mendefiisikan kecerdasan emosional sebagai kemampuan memantau dan mengendalikan perasaan sendiri dan orang lain, serta menggunakan perasaan itu untuk memandu pikiran dan tindakan.

Dari beberapa definisi kecerdasan emosional tersebut, ada kecenderungan arti bahwa kecerdasan emosional adalah kemampuan mengenali perasaan sendiri dan perasaan orang lain, kemampuan memotivasi diri sendiri, kemampuan mengolah emosi dengan baik pada diri sendiri dan orang lain.

Goleman (2015;42) menerangkan suatu konsep bahwasanya ada dua macam kerangka kerja kecakapan emosi, yaitu kecakapan pribadi dan kecakapan sosial. Masing-masing dari kecakapan tersebut memiliki komponen-komponen tertentu yang digabung menjadi 5 komponen. Adapun kelima komponen itu adalah sebagai berikut:

1. Kesadaran Diri; diartikan dengan mengetahui apa yang dirasakan oleh seorang individu pada suatu saat, dan menggunakannya untuk memandu pengambilan keputusan diri sendiri. Kesadaran diri memang penting apabila seseorang ceroboh, tidak memperhatikan dirinya sendiri secara akurat, maka hal itu akan merugikan dirinya sendiri dan berdampak negatif bagi orang lain.

2. Pengaturan diri; Menguasai diri sendiri sedemikian rupa sehingga berdampak positif kepada pelaksanaan tugas, peka terhadap kata hati, dan sanggup menunda kenikmatan sebelum tercapainya sasaran.

3. Motivasi; merupakan kekuatan mental yang mendorong terbentuknya perilaku yang memiliki tujuan tertentu. Dalam motivasi terkandung adanya keinginan, harapan, kebutuhan, tujuan, sasaran dan insentif.

4, Empati; dimaksudkan dengan memahami perasaan atau masalah orang lain dan berfikir dengan sudut pandang mereka, menghargai perbedaan perasaan orang mengenai berbagai hal. Empati menekankan pentingnya mengindra perasaan perspektif orang lain sebagai dasar untuk membangun interpersonal yang sehat.

5. Kemampuan sosial (social skills); adalah kemampuan untuk menangani emosi dengan baik ketika berhubungan dengan orang lain dan dengan cermat membaca situasi dan jaringan sosial, berinteraksi dengan lancar, menggunakan keterampilan untuk mempengaruhi dan memimpin, bermusyawarah dan menyelesaikan perselisihan untuk untuk bekerjasama dalam tim.

Dengan memahami komponen-komponen emosional tersebut, diharapkan seseorang dapat menyalurkan emosinya secara proporsional dan efektif. 
Goleman (2015:67) menyebutkan ada lima wilayah kecerdasan emosional yang dapat dijadikan pedoman bagi pengembangan diri seseorang untuk mencapai kesuksesan dalam kehidupan sehari-hari, yaitu sebagai berikut:

1. Mengenali emosi diri . Kesadaran diri dalam mengenali perasaan sewaktu perasaan itu terjadi merupakan dasar kecerdasan emosional. Ketidakmampuan untuk mencermati perasaan yang sesungguhnya membuat diri berada dalam kekuasaan perasaan. Tidak peka akan perasaan yang sesungguhnya akan berakibat buruk bagi pengambilan keputusan masalah.

2. Mengelola emosi . Menangani perasaan agar perasaan dapat terungkap dengan jelas, hal ini merupakan kecakapan yang sangat bergantung pada kesadaran diri.

3. Memotivasi diri. Dengan kemampuan memotivasi diri yang dimiliki seseorang maka ia akan cenderung memiliki pandangan yang positif dalam menilai segala sesuatu yang terjadi dalam dirinya.

4. Mengenali emosi orang lain. Jika seseorang terbuka pada emosi sendiri, maka dapat dipastikan bahwa ia akan terampil membaca perasaan orang lain. Sebaliknya, orang yang tidak mampu menyesuaikan diri dengan emosinya sendiri dapat dipastikan tidak akan mampu menghormati perasaan orang lain.

\section{Spiritual Quotient (SQ)/Kecerdasan Spiritual}

Seperti halnya kecerdasan emosional, terminologi kecerdasan spiritual dipergunakan untuk mendeskripsikan dimensi lain dari kecerdasan manusia, meskipun hakekatnya kecerdasan spiritual tidak terpisahkan dari kecerdasan intelektual (IQ) dan kecerdasan emosional (EQ), (Darwis , 2004:33), dalam Sitti 2012).

Kecerdasan Spiritual (SQ), merupakan temun terkini secara ilmiah yang ditemukan oleh Danah Zohar dan Ian Marshall pada pertengahan tahun 2002. Zohar dan Marshall 2002 (dalam Ary, 2015:57), menegaskan bahwa kecerdasan spiritual (SQ) adalah landasan untuk memfungsikan dan mensinkronisasi IQ dan EQ secara efektif. SQ merupakan kecerdasan tertinggi kita.

Spiritualitas tidak harus dikaitkan antara kedekatan seseorang dengan aspek ketuhanan, sebab seseorang humanis atau atheis pun dapat memiliki spiritualitas yang tinggi. Kecerdasan spiritual lebih berkaitan dengan pencerahan jiwa. Menurut Ary (2015:58), sebuah penggabungan antara kecerdasan emosi dan kecerdasan spiritual hasilnya adalah kebahagian dan kedamaian pada jiwa seseorang.

Beberapa pendapat mengenai kecerdasan spiritual meurut para ahli, yaitu Ary Ginanjar Agustin (2015) menyatakan bahwa kecerdasan spiritual adalah kemampuan untuk memberi makna ibadah terhadap setiap perilaku dan kegiatan, melalui langkah-langkah dan pemikiran yang bersifat fitrah, menuju manusia yang seutuhnya (hanif) dan Zohar dan Marshall dalam Ary (2015) menyatahan bahwa kecerdasan spiritual adalah kecerdasan untuk menghadapi persoalan makna atau value, yaitu kecerdasan dalam menempatkan perilaku.dan hidup kita dalam konteks makna yang lebih luas dan kaya, kecerdasan untuk menilai bahwa tindakan atau jalan hidup seseorang lebih bermakna dibandingkan dengan yang lain. 
Terdapat beberapa indikator dalam kecerdasan spiritual, yaitu:

1. Religius; Religius berasal dari kata religious yang berarti sifat religi melekat pada diri seseorang.

2. Sifat positif; Sifat positif adalah nyata dari suasana jiwa yang dapat memperhatikan halhal positif.

3. Beretika; Etika dapat didefinisikan secara luas sebagai seperangkat prinsip-prinsip moral atau nila-nilai.

4. Kepeduliaan sosial; Minat atau ketertarikan kita untuk membantu orang lain.

Zohar dan Marshall (dalam Ary, 2015:60) menjelaskan manfaat kecerdasan spiritual bagi manusia, diantaranya adalah:

1. SQ membuat manusia menjadi kreatif.

2. SQ membuat manusia mampu berpikir secara luas dan mendalam.

3. SQ digunakan untuk memecahkan persoalan yang amat mendasar.

4. SQ digunakan sebagai sarana untuk cerdas beragama.

5. SQ digunakan untuk mencapai perkembangan diri yang lebih utuh.

\section{Self Efficacy/Kepercayaan Diri}

Kepercayaan diri juga dikenal sebagai teori kognitif sosial atau teori pembelajaran sosial yaitu mengacu pada keyakinan individu bahwa dia mampu untuk melaksanakan tugas. Semakin tinggi kepercayaan diri, semakin anda percaya diri pada kemampuan untuk berhasil (Stephen \& Timothy, 2015:139).. Robbins, 2009 (dalam Puspita, 2015) menyebutkan bahwa kepercayaan diri yang merujuk pada keyakinan individu bahwa dirinya mampu menjalankan suatu tugas. Semakin tinggi kepercayaan diri, semakin yakin pada kemampuan untuk menyelesaikan tugas atau mengerjakan sesuatu. Jadi, dalam situasi sulit orang dengan kepercayaan diri rendah lebih mungkin mengurangi usaha atau melepaskannya sama sekali, sementara orang dengan kepercayaan diri yang tinggi akan semakin giat mencoba untuk mengatasi tantangan tersebut.

Bandura, 1995 dalam Puspita, 2015, keyakinan mengenai tingkat kepercayaan diri seseorang dapat dikembangkan melalui sumber yang akan dijelaskan sebagai berikut:

1. Pengalaman Keberhasilan (Mastery Experiences)

Keberhasilan yang sering didapatkan akan meningkatkan kepercayaan diri yang dimiliki seseorang, sedangkan kegagalan akan menurunkan kepercayaan diri seseorang.

2. Persuasi Sosial (Social Persuation)

Informasi tentang kemampuan yang disampaikan secara verbal oleh seseorang yang berpengaruh biasanya digunakan untuk meyakinkan seseorang bahwa ia cukup mampu melakukan suatu tugas.

3. Keadaan fisiologis dan emosional (physiological and emotional state)

Kecemasan dan stress yang terjadi dalam diri seseorang ketika melakukan tugas sering diartikan sebagai suatu kegagalan. Kepercayaan diri biasanya ditandai oleh rendahnya tingkat stress dan kecemasan, sebaliknya kepercayaan diri yang rendah ditandai oleh tingkat stress dan kecemasan yang tinggi pula. 
Beberapa hal yang termasuk ke dalam dimensi kepercayaan diri adalah:

1. Level; yaitu sejauh mana individu dapat menentukan tingkat kesulitan dalam pekerjaan yang mampu dilaksanakannya. Penilaian dari aspek ini dapat dilihat dari beberapa hal, yaitu dengan melihat apakah individu dapat membuat yang menantang, yakin dapat melakukan pekerjaan dengan baik, dan apakah individu tersebut mengetahui minatnya dan kemampuannya sehingga dapat memilih pekerjaan yang dirasa sesuai.

2. Strength; yaitu sejauh mana kekuatan atau keyakinan akan level tersebut, apakah kuat atau lemah, yang dapat dilihat dari konsistensi individu tersebut dalam mengerjakan tugasnya.

3. Generality; yaitu bagaimana seseorang mampu menggeneralisasikan tugas-tugas dan pengalaman-pengalaman sebelumnya ketika menghadapi suatu tugas-tugas atau pekerjaan. Misalnya, apakah ia dapat menjadikan pengalaman atau menjadi suatu hambatan atau bahkan diartikan sebagai kegagalan.

\section{METODELOGI PENELITIAN}

\section{Jenis Data}

Dalam penelitian ini, peneliti menggunakan data primer untuk mengukur variabel independen (Intelligence Quoetient (IQ)/Kecerdasan Intelektual, Emotional Quoetient (EQ)/Kecerdasan Emosional, Spiritual Quoetient (SQ)/Kecerdasan Spiritual dan Self Efficacy/Kepercayaan Diri) serta variabel dependen (Kinerja Auditor) yang diambil dari penyebaran kuesioner kepada individu atau perorangan auditor.

\section{Populasi dan Sampel}

Dalam penelitian ini, populasi yang diambil adalah sebagian auditor yang bekerja di 10 Kantor Akuntan Publik yang terdaftar di IAPI tahun 2016 di Wilayah Jakarta Selatan. Metode pengumpulan sampel adalah metode Purposive Sampling yaitu metode pengambilan sampel berdasarkan kriteria tertentu yang ditetapkan peneliti secara objektif.

\section{Metode Analisis Data dan Hipotesis}

Skala pengukuran yang digunakan dengan merubah skala ordinal ke interval dengan tipe skala Likert lima (5) poin dengan rentang angka 1-5 yang memberikan gambaran sampai seberapa jauh responden melaksanakan fungsi sesuai dengan pernyataan yang diberikan. Metode statitika yang digunkan dalam menguji hipotesis dalam penelitian ini adalah dengan Regresi Liniear Berganda dengan menggunakan program Statistik Program Social Science (SPSS) versi 21.0. Sebelum menganalisi data akan diuji validitas dan reliabilitas serta uji asumsi klasik. Hipotesis dilakukan dengan menggunakan uji parsial(uji t) dan simultan (uji F) dengan tingkat signifikansi 0,05 atau 5\% .

\section{HASIL ANALISIS DATA DAN PEMBAHASAN}

\section{Demografi Responden Penelitian}

Demografi penyebaran dan hasil yang diperoleh dari responden direkapitulasi berdasarkan berbagai hal seperti; jenis kelamin, usia, tingkat pendidikan , jabatan responden dan masa kerja responden, dapat dilihat pada table berikut : 
Tabel

Responden

\begin{tabular}{|c|c|c|c|}
\hline \multicolumn{2}{|c|}{ Kriteria dan Ukuran Sample } & Frequency & Percent \\
\hline \multirow{3}{*}{ Kuesioner } & Disebar & 100 & $100,00 \%$ \\
\hline & Yang tidak kembali & 6 & $6,00 \%$ \\
\hline & Total kembali dan diolah & 94 & $94,00 \%$ \\
\hline \multirow{3}{*}{ Jenis Kelamin } & Laki - laki & 50 & $53,19 \%$ \\
\hline & Perempuan & 44 & $46,81 \%$ \\
\hline & Total & 94 & $100 \%$ \\
\hline \multirow{4}{*}{ Usia } & $20-30$ tahun & 78 & $82,98 \%$ \\
\hline & $31-40$ tahun & 13 & $13,83 \%$ \\
\hline & Di atas 40 tahun & 3 & $3,19 \%$ \\
\hline & Total & 94 & $100 \%$ \\
\hline \multirow{3}{*}{$\begin{array}{c}\text { Jenjang } \\
\text { Pendidikan }\end{array}$} & $\mathrm{S} 1$ & 92 & $97,87 \%$ \\
\hline & $\mathrm{S} 2$ & 2 & $2,13 \%$ \\
\hline & Total & 94 & $100 \%$ \\
\hline \multirow{5}{*}{ Jabatan } & Manager & 2 & $2,13 \%$ \\
\hline & Supervisor & 2 & $2,13 \%$ \\
\hline & Senior & 30 & $31,91 \%$ \\
\hline & Junior & 60 & $63,83 \%$ \\
\hline & Total & 94 & $100 \%$ \\
\hline \multirow{5}{*}{ Masa Kerja } & $1-3$ tahun & 75 & $79,79 \%$ \\
\hline & $4-6$ tahun & 11 & $11,70 \%$ \\
\hline & $7-10$ tahun & 6 & $6,38 \%$ \\
\hline & $>10$ tahun & 2 & $2,13 \%$ \\
\hline & Total & 94 & $100 \%$ \\
\hline
\end{tabular}

\section{Uji Pendahuluan \\ Uji Validitas}

Menurut Ghozali (2013), suatu variabel dikatakan valid apabila nilai $r_{\text {hitung }}>r_{\text {tabel }}$. Nilai $\mathrm{t}_{\text {tabel }}$ diperoleh melalui rumus df (degree of freedom $)=\mathrm{n}-\mathrm{k}-1$ dimana $\mathrm{n}$ adalah jumlah responden dan $\mathrm{k}$ merupakan jumlah content (variabel independen), sedangkan 1 merupakan uji satu sisi sehingga $r$ table adalah 0,206 dengan taraf signifikansi $\alpha=5 \%$. Tabel berikut ini menunjukkan hasil uji validitas

Tabel

\section{Uji Validtas}

\begin{tabular}{|c|c|c|}
\hline Variabel Penelitian & $\begin{array}{c}\text { Corrected Item-Total } \\
\text { Correlation }\end{array}$ & $\begin{array}{c}\text { Total Ques } \\
\text { tioner }\end{array}$ \\
\hline Kecerdasan Intelektual /IQ (X1) & $0,410 \quad$ s/d 0,627 & 7 \\
Kecerdasan Emosional/EQ (X2) & 0,315 s/d 0,544 & 15 \\
Kecerdasan Spiritual/SQ (X3) & $0,244 \quad$ s/d 0,643 & 12 \\
Kepercayaan Diri/SE $\quad(X 4)$ & $0,251 \quad$ s/d 0,545 & 7 \\
Kinerja Auditor (Y) & $0,268 \quad$ s/d 0,599 & 10 \\
\hline
\end{tabular}


Dari hasil table di atas uji validitas tersebut diketahui bahwa r-hitung lebih besar dari rtabel 0,233 , sehingga semua variable yang diuji adalah valid.

\section{Uji Reliabilitas}

Uji reliabilitas digunakan untuk menunjukkan ukuran kestabilan dan konsistensi dari konsep ukuran instrumen atau alat ukur, sehingga nilai yang diukur tidak berubah dalam nilai tertentu. Suatu variabel dikatakan reliabel apabila memberikan nilai Cronbach's Alpha $\geq 0,60$ . Tabel berikut, menunjukkan hasil uji reliabilitas.

Tabel

\section{Uji Reliabilitas}

\begin{tabular}{|c|c|c|}
\hline Variabel Penelitian & $\begin{array}{c}\text { Cronbach's } \\
\text { Alpha }\end{array}$ & N of Items \\
\hline Kecerdasan Intelektual /IQ (X1) & 0,789 & 7 \\
Kecerdasan Emosional/EQ (X2) & 0,816 & 15 \\
Kecerdasan Spiritual/SQ (X3) & 0,806 & 12 \\
Kepercayaan Diri/SE (X4) & 0,690 & 7 \\
Kinerja Auditor (Y) & 0,752 & 10 \\
\hline
\end{tabular}

Dari hasil uji reliabilitas diketahui bahwa Cronbach's Alpha lebih besar dari 0,60, sehingga semua variable yang diuji dinyatakan reliable.

\section{Uji Asumsi Klasik}

Sebelum dilakukan analisa regresi terhadap variabel-variabel penelitian terlebih dahulu dilakukan uji asumsi klasik. Tujuannya adalah agar data yang digunakan layak dijadikan sumber pengujian dan dapat dihasilkan kesimpulan yang benar.

\section{a. Uji Normalitas}

Uji Normalitas bertujuan untuk menguji apakah dalam model regresi, variabel bebas dan terikat memiliki distribusi normal dan mengetahui distribusi data dalam suatu variabel yang akan digunakan dalam sebuah penelitian apakah data layak atau tidak dianalisis. Model regresi yang baik adalah memiliki distribusi data normal. Dalam penelitian ini Normalitas dapat diketahui dengan melihat tabel One-Sample Kolmogorov - Smirnov Test pada kolom Asymp, Sig (2-tailed) yaitu data dikatakan berdistribusi normal apabila $p$ value (sig) $>0,05$. Tabel berikut menunjukkan hasil uji normalitas.

\section{Tabel}

\section{One-Sample Kolmogorov-Smirnov Test}

\begin{tabular}{|c|c|c|r|r|c|}
\hline & $X 1$ & $\mathrm{X} 2$ & \multicolumn{1}{|c|}{ X3 } & \multicolumn{1}{c|}{ X4 } & Y \\
\hline $\mathrm{N}$ & 94 & 94 & 94 & 94 & 94 \\
Kolmogorov-Smirnov Z &, 893 & 1,066 & 1,053 & 1,161 &, 823 \\
Asymp. Sig. (2-tailed) &, 402 &, 206 &, 217 &, 135 &, 507 \\
\hline
\end{tabular}

a. Test distribution is Normal.

b. Calculated from data. 
Dari hasil uji normalitas tersebut diketahui bahwa Sample Kolmogorov - Smirnov Test pada kolom Asymp, Sig (2-tailed) atau $p$ value (sig) $>0,05$, sehingga semua variable yang diuji dinyatakan terdistribusi normal.

\section{b. Uji Multikolonieritas}

Uji multikolinearitas bertujuan untuk menguji apakah model regresi ditemukan adanya korelasi antar variabel bebas (independen). Model regresi yang baik seharusnya tidak terdapat korelasi antara variabel independen. Uji multikolinieritas dapat dilakukan dengan 2 cara yaitu dengan melihat (1) nilai tolerance dan lawannya (2) VIF (Variance Inflation Factors). Jika tolerance $<0,10$ dan nilai VIF $>10$ maka terjadi gejala Multikolinieritas, dan sebaliknya (Ghozali, 2011:105). Tabel berikut menunjukkan hasil uji multikolinieritas .

\section{Tabel}

\begin{tabular}{|c|r|r|}
\hline Model & \multicolumn{3}{|c|}{$\begin{array}{c}\text { Collinearity Statistics } \\
\text { Tolerance }\end{array}$} \\
\hline (Constant) & & \\
Kecerdasan Intelektual /IQ (X1 &, 897 & 1,115 \\
Kecerdasan Emosional/EQ (X2) &, 857 & 1,167 \\
Kecerdasan Spiritual/SQ (X3) &, 901 & 1,110 \\
\hline Kepercayaan Diri/SE (X4) &, 842 & 1,188 \\
\hline
\end{tabular}

a. Dependent Variable: Kinerja Auditor (Y)

Dari tabel di atas dapat diketahui bahwa nilai Variance Inflation Factor (VIF) keempat variabel Kecerdasan Intelektual, Kecerdasan Emosional, Kecerdasan Spritual, dan Kepercayaan Diri adalah kurang dari 10 dan nilai tolerance diatas 0,10 sehingga dapat disimpulkan bahwa antar variabel independen tidak terjadi multikolonieritas sehingga layak digunakan.

\section{c. Uji Heteroskedastisitas}

Menurut Ghozali (2016:139), uji heteroskedastisitas bertujuan untuk menguji apakah dalam model regresi terjadi ketidaksamaan variance dari residual satu pengamatan ke pengamatan lain. Jika variance dari residual satu pengamatan ke pengamatan lain Model regresi yang baik adalah yang homoskedastisitas atau tidak terjadi tetap, maka disebut homoskedastisitas dan jika berbeda disebut heteroskedastisitas.

Terdeteksi atau tidaknya heteroskedastisitas dapat dilihat dengan ada tidaknya pola tertentu pada grafik Scatterplot. Jika ada pola tertentu maka mengidentifikasikan telah terjadi heteroskedastisitas. Tetapi jika tidak ada pola yang jelas serta titik-titik menyebar di atas dan di bawah angka 0 pada sumbu Y, maka tidak terjadi heteroskedastisitas. Gambar berikut menunjukkan hasil ujinya . 


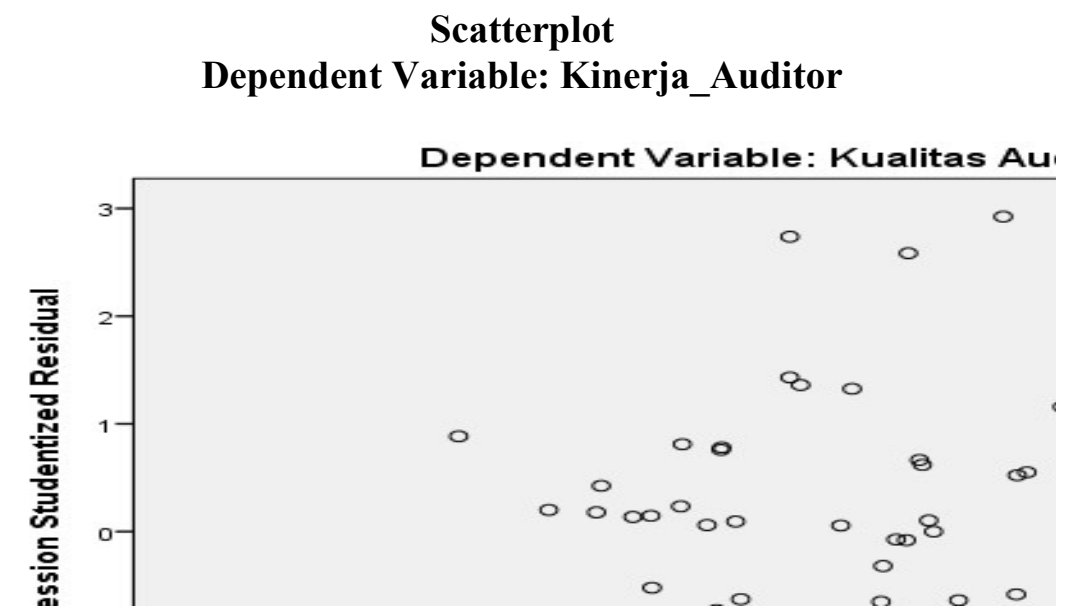

Dari output scatterplot dapat diketahui bahwa titik-titik tidak membentuk pola yang jelas, dan titik-titik menyebar di atas dan di bawah angka 0 dan pada sumbu Y. Jadi dapat disimpulkan bahwa tidak terjadi heteroskedastisitas dalam model regresi, sehingga model regresi layak digunakan memprediksi kinerja auditor berdasarkan variable independen kecerdasan intelektual, kecerdasan emosional, kecerdasan spiritual dan kepercayaan diri.

\section{d. Uji Autokorelasi}

Autokorelasi merupakan korelasi antara anggota observasi yang disusun menurut waktu dan tempat. Model regresi yang baik seharusnya tidak terjadi autokorelasi. Model pengujian menggunakan uji Durbin-Watson (DW test) dengan ketentuan sebagai berikut:

1. $\mathrm{dU}<\mathrm{DW}<4$-dU maka Ho diterima, artinya tidak terjadi autokorelasi

2. DW $<\mathrm{dL}$ atau DW $>4$-dL maka Ho ditolak, artinya terjadi autokorelasi.

3. $\mathrm{dL}<\mathrm{DW}<\mathrm{dU}$ atau 4-dU $<\mathrm{DW}<4$-dL, artinya tidak ada kepastian atau kesimpulan yang pasti.

Nilai dU dan dL dapat diperoleh dari tabel statistik Durbin-Watson. Berdasarkan tabel statistik Durbin-Watson, dengan signifikan 0,05 dan jumlah data (n) $=94$, serta $\mathrm{k}=4$ , diperoleh nilai dL sebesar 1,576 dan nilai dU sebesar 1,753. Nasil uji autokorelasi dalam model regresi dapat dilihat pada tabel berikut ini:

Tabel

Model Summary

\begin{tabular}{|l|r|r|r|r|r|}
\hline Model & $\mathrm{R}$ & $\begin{array}{c}\mathrm{R} \\
\text { Square }\end{array}$ & $\begin{array}{c}\text { Adjusted R } \\
\text { Square }\end{array}$ & $\begin{array}{c}\text { Std. Error of } \\
\text { the Estimate }\end{array}$ & Durbin-Watson \\
\hline 1 &, $697^{\mathrm{a}}$ &, 486 &, 463 & 2,391 & 1,800 \\
\hline
\end{tabular}

a. Predictors: (Constant), Self Efficacy (X4), Intelligence Quotient (X1), Spiritual Quotient (X3), Emotional Quotient (X2)a

b. Dependent Variable: Kinerja Auditor (Y)

Dari hasil output di atas dapat diketahui nilai DW yang dihasilkan dari model regresi adalah 1,800. karena nilai DW terletak antara dU dan 4-dU $(1,753<1,800<$ 2,247), maka Ho diterima, yang berarti tidak ada autokorelasi pada model regresi. 


\section{Analisis Regresi Linier Berganda}

Analisa regresi linier berganda digunakan untuk mengetahui pengaruh atau hubungan secara linier antara variabel bebas yaitu Kecerdasan Intelektual, Kecerdasan Emosional, Kecerdasan Spritual, dan Kepercayaan Diri terhadap variabel terikat yaitu Kinerja Auditor.

Tabel

Coefficients $^{\mathrm{a}}$

\begin{tabular}{|c|c|c|c|c|c|c|c|}
\hline \multirow[t]{2}{*}{ Model } & \multicolumn{2}{|c|}{$\begin{array}{l}\text { Unstandardized } \\
\text { Coefficients }\end{array}$} & \multirow{2}{*}{$\begin{array}{c}\begin{array}{c}\text { Standardi } \\
\text { zed } \\
\text { Coefficie } \\
\text { nts }\end{array} \\
\text { Beta }\end{array}$} & \multirow[t]{2}{*}{$\mathrm{T}$} & \multirow[t]{2}{*}{ Sig. } & \multicolumn{2}{|c|}{$\begin{array}{c}\text { Collinearity } \\
\text { Statistics }\end{array}$} \\
\hline & B & $\begin{array}{l}\text { Std. } \\
\text { Error }\end{array}$ & & & & Tolerance & VIF \\
\hline (Constant) & 4,546 & 5,202 & & ,874 & ,385 & & \\
\hline $\begin{array}{l}\text { Kecerdasan Intelektual } \\
\text { (X1) }\end{array}$ &, 175 & ,088 & ,161 & 2,002 & ,048 & ,897 & 1,115 \\
\hline $\begin{array}{l}\text { Kecerdasan Emosional } \\
\text { (X2) }\end{array}$ & ,069 & ,061 & ,093 & 1,132 & ,261 &, 857 & 1,167 \\
\hline $\begin{array}{l}\text { Kecerdasan Spiritual } \\
\text { (X3) }\end{array}$ &, 049 & ,076 &, 051 & ,643 &, 522 & ,901 & 1,110 \\
\hline Kepercayaan Diri (X4) & ,875 & , 122 & ,594 & 7,167 &, 000 & ,842 & 1,188 \\
\hline
\end{tabular}

a. Dependent Variable: Kualitas Audit (Y) berikut :

Dari tabel di atas dapat diketahui model persamaan regresi linier berganda sebagai

$$
\begin{gathered}
Y=a+\beta 1 X 1+\beta 2 X 2+\beta 3 X 3+\beta 4 X 4+\varepsilon \\
Y=4,546+0,175 X 1+0,069 X 2+0,049 X 3+0,875 X 4+\varepsilon
\end{gathered}
$$

Persamaan di atas dapat dijelaskan sebagai berikut:

1. Nilai konstanta sebesar 4,546 artinya, jika Intelligence Quoetient (IQ)/Kecerdasan Intelektual $\left(\mathrm{X}_{1}\right)$, Emotional Quoetient (EQ)/Kecerdasan Emosional ( $\left.\mathrm{X}_{2}\right)$, Spiritual Quotient (SQ)/Kecerdasan Spritual $\left(\mathrm{X}_{3}\right)$, Self Efficacy/Kepercayaan $\left(\mathrm{X}_{4}\right)$ nilainya 0 maka Kinerja Auditor (Y) nilainya sebesar 4,546.

2. Nilai koefisien regresi variabel Intelligence Quoetient (IQ)/Kecerdasan Intelektual $\left(\mathrm{X}_{1}\right)$ sebesar 0,175 artinya, bahwa setiap peningkatan Intelligence Quoetient (IQ)/Kecerdasan Intelektual sebesar 1, maka akan meningkatkan variabel Kinerja Auditor (Y) sebesar 0,175 atau 17,5\%.

3. Nilai koefisien regresi variabel Emotional Quoetient (EQ)/Kecerdasan Emosional $\left(\mathrm{X}_{2}\right)$ sebesar 0,069 artinya, bahwa setiap peningkatan Emotional Quoetient (EQ)/Kecerdasan Emosional $\left(\mathrm{X}_{2}\right)$ sebesar 1, maka akan meningkatkan variabel Kinerja Auditor (Y) sebesar 0,069 atau 6,9\%.

4. Nilai koefisien regresi variabel Spiritual Quotient (SQ)/Kecerdasan Spritual $\left(\mathrm{X}_{3}\right)$ sebesar 0,049 artinya, bahwa setiap peningkatan Spiritual Quotient (SQ)/Kecerdasan 
Spritual sebesar 1, maka variabel Kinerja Auditor (Y) akan meningkat sebesar 0,049 atau $4,9 \%$.

5. Nilai koefisien regresi variabel Self Efficacy/Kepercayaan Diri $\left(\mathrm{X}_{4}\right)$ sebesar 0,875 artinya, bahwa setiap peningkatan Self Efficacy/Kepercayaan Diri $\left(\mathrm{X}_{4}\right)$ sebesar 1, maka akan meningkatkan variabel Kinerja Auditor sebesar 0,875 atau 87,5\%.

\section{Hipothesis}

\section{Uji Parsial ( Uji - t )}

Uji t yaitu suatu uji untuk mengetahui signifikansi pengaruh variabel bebas (Kecerdasan Intelektual $\left(\mathrm{X}_{1}\right)$, Kecerdasan Emosional $\left(\mathrm{X}_{2}\right)$, Kecerdasan Spritual ( $\left.\mathrm{X}_{3}\right)$, Kepercayaan $\left(\mathrm{X}_{4}\right)$ ) secara parsial atau individual menerangkan terhadap variabel terikat (Kinerja Auditor(Y)). Pengujian ini dinilai dengan taraf signifikansi $\alpha=5 \%$. Selanjutnya untuk mengetahui signifikan pengaruh atau hubungan antara variabel dilakukan dengan kriteria pengujian "jika Sig < 0.05, maka Ho ditolak dan Ha diterima atau sebaliknya".

Menentukan nilai tabel juga dapat ditentukan dengan tingkat signifikasi 5\% dengan derajat kebebasan $\mathrm{df}=(\mathrm{n}-\mathrm{k}-1)$ dimana $\mathrm{n}$ adalah jumlah responden dan $\mathrm{k}$ adalah jumlah variabel. $T$ tabel dapat dilihat pada tabel statistik pada signifikansi 0.05 dengan derajat kebebasan $(\mathrm{df})=\mathrm{n}-\mathrm{k}-1=94-4-1=89$. Hasil yang diperoleh untuk tabel sebesar 1.662, Kriteria pengujian yang digunakan adalah jika $t_{\text {hitung }}>t_{\text {tabel }}(n-k-1)$ maka Ho ditolak dan Ha diterima atau sebaliknya.

Berdasarkan tabel Coefficient yang telah diperoleh dari koefisien regresi di atas, maka dapat hasil uji parsial(uji t) sebagai berikut :

\section{a. Pengaruh Intelligence Quoetient (IQ)/Kecerdasan Intelektual $\left(\mathrm{X}_{1}\right)$ Berpengaruh Positif dan Signifikan Terhadap Kinerja Auditor (Y)}

Hasil pengujian statistik menunjukkan bahwa kecerdasan intelektual mempunyai

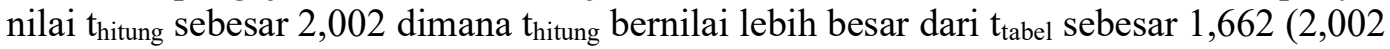
$>1,662$ ) dan tingkat signifikan sebesar 0,048. Hal ini dapat dinyatakan bahwa Ho ditolak dan Ha diterima, artinya bahwa kecerdasan intelektual berpengaruh secara signifikan dan positif terhadap kinerja auditor sebesar 17,5\%. Penerapan kecerdasan intelektual yang maksimal tentunya akan sejalan dengan semakin bertambahnya keahlian yang dimiliki, sehingga mampu menghasilkan kinerja auditor yang baik.

\section{b. Emotional Quoetient (EQ)/Kecerdasan Emosional $\left(\mathrm{X}_{2}\right)$ Tidak Berpengaruh Secara Signifikan dan Positif Terhadap Kinerja Auditor (Y)}

Hasil pengujian statistik menunjukkan bahwa kecerdasan emosional mempunyai nilai $t_{\text {hitung }}$ sebesar 1,132 dimana $t_{\text {hitung }}$ bernilai lebih kecil dari $t_{\text {tabel }}$ sebesar 1,662 (1,132 $<$ 1,662) dan tingkat signifikan sebesar 0,261. Hal ini dapat dinyatakan bahwa Ho diterima dan Ha ditolak, artinya bahwa kecerdasan emosional tidak berpengaruh secara signifikan dan positif terhadap kinerja auditor hanya sebesar 6,9\%. Kecerdasan emosional menunjukkan hubungan yang sangat lemah untuk saling mempengaruhi antara kecerdasan emosional dengan kinerja auditor. Hasil penelitian ini dipengaruhi oleh beberapa fakta yang berhubungan dengan responden sebanyak 78 dari 94 total responden atau $83 \%$ masih relatif muda yang umumnya masih belum dapat mengendalikan emosi dan tunduk terhadap atasan, belum menghadapi konflik peran sehingga belum memahami secara baik dan mendalam tentang makna atau value, juga 
karena mayoritas responden $63,8 \%$ masih junior auditor, sebagai pelaksana prosedur bukan pengambil keputusan akhir.

\section{c. Spiritual Quotient (SQ)/Kecerdasan Spiritual $\left(\mathrm{X}_{3}\right)$ Tidak Berpengaruh Secara Signifikan dan Positif Terhadap Kinerja Auditor (Y)}

Hasil pengujian statistik menunjukkan bahwa kecerdasan spiritual mempunyai nilai

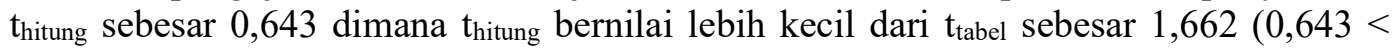
1,662) dan tingkat signifikan sebesar 0,522. Hal ini dapat dinyatakan bahwa Ho diterima dan Ha ditolak, artinya bahwa kecerdasan spiritual tidak berpengaruh secara signifikan dan positif terhadap kinerja auditor hanya sebesar 4,9\%. Kecerdasan spiritual menunjukkan hubungan yang sangat lemah untuk saling mempengaruhi antara kecerdasan emosional dengan kinerja auditor

Hasil penelitian ini dipengaruhi oleh beberapa fakta ; sebesar 83\% responden masih relatif muda dan belum menghadapi konflik peran, belum memahami makna atau value, juga karena mayoritas responden dalam penelitian ini adalah $63,8 \%$ junior auditor. Dengan penggabungan antara kecerdasan emosional dan kecerdasan spiritual hasilnya adalah kebahagiaan dan kedamaian pada jiwa seseorang sehingga dapat menghasilkan kinerja yang baik dan optimal.

\section{d. Self Efficacy/Kepercayaan Diri (X4) Berpengaruh Secara Signifikan dan Positif Terhadap Kinerja Auditor (Y)}

Hasil pengujian statistik menunjukkan bahwa kecerdasan intelektual mempunyai nilai $t_{\text {hitung }}$ sebesar 7,167 dimana $t_{\text {hitung }}$ bernilai lebih besar dari $t_{\text {tabel }}$ sebesar 1,662 (7,167 $>1,662$ ) dan tingkat signifikan sebesar 0,000. Hal ini dapat dinyatakan bahwa Ho ditolak dan Ha diterima, artinya bahwa kepercayaan diri berpengaruh secara signifikan dan positif terhadap kinerja auditor sebesar $87,5 \%$. Kepercayaan diri menunjukkan hubungan yang kuat untuk saling mempengaruhi antara kepercayaan diri dengan kinerja auditor

Kepercayaan diri yang tinggi dapat mengembangkan kepribadian yang kuat. Jika kepercayaan diri rendah akan menghambat dan memperlambat perkembangan dari kemampuan auditor tersebut. Tingkat kecemasan dan stress yang terjadi dalam diri seseorang ketika melakukan pekerjaan juga dapat mempengaruhi kepercayaan diri. Semakin rendah tingkat kecemasan dan stress seorang auditor maka semakin tinggi kepercayaan dirinya dalam melaksanakan tugas dan sebaliknya.

\section{Uji Simultan ( Uji F )}

Uji $\mathrm{F}$ digunakan untuk mengetahui ada tidaknya pengaruh secara besama-sama (simultan) variabel bebas yaitu Intelligence Quoetient (IQ)/Kecerdasan Intelektual $\left(\mathrm{X}_{1}\right)$, Emotional Quoetient (EQ)/Kecerdasan Emosional $\left(\mathrm{X}_{2}\right)$, Spiritual Quotient (SQ)/Kecerdasan Spritual $\left(\mathrm{X}_{3}\right)$, Self Efficacy/Kepercayaan Diri $\left(\mathrm{X}_{4}\right)$ terhadap variabel terikat yaitu Kinerja Auditor (Y). Pembuktian dilakukan dengan cara membandingkan nilai $\mathrm{F}_{\text {hitung }}$ dengan $\mathrm{F}_{\text {tabel }}$ pada tingkat kepercayaan 5\% dan derajat kebebasan (degree of freedom $) \mathrm{df}=(\mathrm{n}-\mathrm{k}-1)$ dimana $\mathrm{n}$ adalah jumlah responden dan $\mathrm{k}$ adalah jumlah variable, sehingga $F$ table dalam pengujian diperoleh dari hasil output SPSS dalam ANOVA, dari tabel $\mathrm{df}=\mathrm{n}-\mathrm{k}-1=94-4-1=89$, hasil yang diperoleh untuk $\mathrm{F}_{\text {tabel }}$ adalah 2,47 . Kriteria pengujian yang digunakan yaitu jika $F_{\text {hitung }}>F_{\text {tabel }}$ (n-k-1) maka Ho ditolak, Ha diterimadan sebaliknya. Selain itu uji $\mathrm{F}$ dapat pula dilihat dari besarnya probabilitas value 
( $p$ value) dibandingkan dengan $0,05(\alpha=5 \%)$. Jika $\mathrm{p}$ value $<0,05$ maka Ho ditolak, Ha diterima dan sebaliknya.

Hasil uji F dapat dilihat pada table berikut ini :

\section{Tabel}

ANOVA ${ }^{\mathrm{a}}$

\begin{tabular}{|c|c|r|r|r|r|}
\hline Model & $\begin{array}{c}\text { Sum of } \\
\text { Squares }\end{array}$ & Df & $\begin{array}{c}\text { Mean } \\
\text { Square }\end{array}$ & F & Sig. \\
\hline Regression & 480,914 & 4 & 120,228 & 21,035 &, $000^{\mathrm{b}}$ \\
1 Residual & 508,703 & 89 & 5,716 & & \\
Total & 989,617 & 93 & & & \\
\hline
\end{tabular}

a. Dependent Variable: Kinerja Auditor (Y)

b. Predictors: (Constant), Self Efficacy (X4), Intelligence Quotient (X1), Spiritual Quotient (X3), Emotional Quotient (X2)

Berdasarkan output di atas dapat disimpulkan bahwa hasil $\mathrm{F}_{\text {hitung }}$ sebesar 21,035, artinya $F_{\text {hitung }}>F_{\text {tabel }}(21,035>2,47)$ dengan tingkat signifikan $0,000<0,05$, dengan demikian Ho ditolak dengan Ha diterima, sehingga terbukti bahwa Intelligence Quoetient (IQ)/Kecerdasan Intelektual, Emotional Quoetient (EQ)/Kecerdasan Emosional, Spiritual Quotient (SQ)/Kecerdasan Spritual, dan Self Efficacy/Kepercayaan Diri secara simultan berpengaruh secara signifikan dan positif terhadap Kinerja Auditor sebesar 46,3\% dan sisanya $53,7 \%$ dipengaruhi oleh faktor lain yang tidak masuk dalam penelitian.

Kinerja auditor merupakan hasil kerja yang dicapai oleh auditor dalam melaksanakan tugasnya sesuai dengan tanggung jawab yang diberikan padanya, dan menjadi salah satu tolak ukur yang digunakan untuk menentukan apakah suatu pekerjaan yang dilakukan akan baik atau sebaliknya. Kinerja auditor menjadi perhatian utama, baik bagi klien ataupun publik dalam menilai hasil audit yang dilakukan.

\section{Kesimpulan}

\section{KESIMPULAN DAN SARAN}

Berdasarkan hasil penelitian mengenai pengaruh Intelligence Quoetient (IQ)/Kecerdasan Intelektual, Emotional Quoetient (EQ)/Kecerdasan Emosional, Spiritual Quotient (SQ)/Kecerdasan Spritual, Self Efficacy/Kepercayaan Diri terhadap Kinerja Auditor yang dilakukan pada Kantor Akuntan Publik di Wilayah Jakarta Selatan, maka dapat ditarik kesimpulan sebagai berikut:

1. Intelligence Quoetient (IQ)/Kecerdasan Intelektual berpengaruh secara signifikan dan positif terhadap kinerja auditor.

2. Emotional Quoetient (EQ)/Kecerdasan Emosional tidak berpengaruh secara signifikan dan positif terhadap kinerja auditor.

3.Spiritual Quotient (SQ)/Kecerdasan Spritual Spiritual Quotient (SQ)/Kecerdasan Spritual tidak berpengaruh secara signifikan dan positif terhadap kinerja auditor..

4. Self Efficacy/Kepercayaan Diri berpengaruh secara signifikan dan positif terhadap kinerja auditor.

5. Intelligence Quoetient (IQ)/Kecerdasan Intelektual, Emotional Quoetient (EQ)/Kecerdasan Emosional, Spiritual Quotient (SQ)/Kecerdasan Spritual, Self Efficacy/Kepercayaan Diri secara bersama-sama berpengaruh signifikan dan positif terhadap Kinerja Auditor terhadap Kinerja Auditor. 


\section{Saran}

Harapan penulis pada penelitian selanjutnya diharapkan dapat memperbaiki kekurangankekurangan penelitian ini diantaranya:

1. Melakukan penelitian dalam lingkup yang lebih luas dengan waktu yang cukup, sehingga dapat diperoleh data yang cukup dan hasil analisa akan jauh lebih akurat.

2. Peneliti selanjutnya diharapkan lebih banyak memberikan kuesioner kepada senior auditor, auditor yang memiliki pengalaman kerja lebih dari 2 tahun karena auditor yang memiliki kategori tersebut memiliki banyak pengalaman di lapangan.

3. Peneliti menyarankan agar peneliti berikutnya memperoleh data tidak hanya degan menggunakan kuesioner, namun juga dengan instrumen lain seperti wawancara, pengamatan, dan lainnya.

4. Mengembangkan penelitian dengan menambahkan faktor-faktor atau variabel lain di luar model penelitian ini dan pengembangan ilmu pengetahuan secara akademik yang digunakan untuk penelitian-penelitian berikutnya.

\section{DAFTAR PUSTAKA}

\section{Buku - Buku :}

Abdul Halim. 2008, Auditing 1 Dasar-dasar Audit Laporan Keuangan. Y Yogyakarta : UPP AMP YKPN.

Agoes, Soekirno. 2016 Auditing Petunjuk Praktik Pemeriksaan Akuntan Oleh Akuntan Publik, Salemba Empat, Jakarta.

Agustian, Ary Ginanjar. 2016. Rahasia Sukses Membangun Kecerdasan Emosi dan Spiritual (ESQ). Arga. Jakarta.

Arens dan Loebbecke. 2011. Auditing Pendekatan Terpadu. Edisi Indonesia, Salemba Empat, Jakarta.

Ghozali, Imam. 2016. Aplikasi Analisis Multivariate dengan Program IBM SPSS 23, Edisi 8. Badan Penerbit Universitas Diponogoro. Semarang.

Goleman, Daniel. 2015. Emotional Intelligence / Kecerdasan Emosional, Edisi $10 \quad$ PT. Gramedia Pustaka Umum . Jakarta.

Mangkunegara, Anwar, 2013, Manajemen Sumber Daya Manusia Perusahaan Remaja Rosdakarya. Bandung

Mulyadi.2012. Auditing Edisi ke-6, Salemba Empat. Jakarta.

Ridwan \& Engkos, K. A (2007). Cara Menggunakan dan Memaknai Analisis Jalur (Path Analysis). Cetakan Pertama. Bandung: Alphabeta.

Standar Profesional Akuntan Publik (SPAP) .2011. Institut Akuntan Publik Indonesia.Jakarta: Salemba Empat.

Sogiyono, 2015. Metode Penelitian Kuantitatif, Kualitatif, dan R\&D. Alfabeta. Bandung.

Robbins, Stephen P dan Timothy A.Judge, Perilaku Organisasi. 2015.Jakarta: $\quad$ Salemba Empat.

Sternberg, J. Robert. 2008. Psikologi Kognitif. Yogyakarta: Pustaka

Pelajar.

Undang Undang Republik Indonesia No. 5 Tahun 2011 tentang “Akuntan

Publik". 


\section{Jurnal - Jurnal :}

Choiriah Anis, 2013. Pengaruh Kecerdasan Emosional, Kecerdasan Intelektual, Kecerdasan Spiritual, Dan Etika Profesi Terhadap Kinerja Auditor Dalam Kantor Akuntan Publik (Studi Empiris Pada Auditor dalam Kantor AkuntanPublik di Kota Padang dan Pekanbaru). Jurnal Ilmiah Fakultas Ekonomi, Universitas Padang. Padang

Idrus, Muhammad. 2002. Kecerdasan Spiritual Mahasiswa Yogyakarta, Psikologi Phronesis, Jurnal Ilmiah dan Terapan, Vo.4, No.8, Desember 2002

Kristiyanti. Lms, 2015. Pengaruh Emotional Quotient Dan Self Efficacy Terhadap Kinerja Auditor (Studi Kasus Kantor Akuntan di Surakarta dan Yogyakarta). Jurnal Akuntansi dan Pajak Vol. 16 No. 01, Juli 2015. ISSN : 1412 629X

Made dan Yuliana, 2016. Pengaruh Kecerdasan Emosional, Kecerdasan Spiritual, Kecerdasan Intelektual Dan Independensi Pada Kinerja Auditor. ISSN: 23028556. E-Jurnal Akuntansi Universitas Udayana.Vol.16.2. Agustus (2016)

Putri, Kompiang Martina Dinata dan I.D.G Dharma Saputra. 2013. Pengaruh Independensi, Profesionalisme, dan Etika Profesi Terhadap Kinerja Auditorpada Kantor Akuntan Publik di Bali. E-Jurnal Akuntansi Universitas Udayana Vol. 4 (1). pp: 39-53

R.A Fabiola Martin.2005. Analisis Pengaruh Kecerdasan Intelektual, Kecerdasan Emosi dan Kecerdasan Spiritual terhadap Kinerja Karyawan. Universitas Diponegoro. Semarang.

Tjun, Law Tjun, Elyzabet Indrawati Marpaung dan Santy Setiawan. 2012. Pengaruh Kompetensi dan Independensi Auditor Terhadap Kinerja Audit. Jurnal Akuntansi . Vol. 4 (1).

Widyastary, Ida Ayu Paramita, Gerianta Wirawan Yasa dan Made Gede Wirakusuma.2014. Pengaruh Konflik Peran, Ketidakjelasan Peran dan Kelebihan Peran pada Kinerja Auditor dengan Kecerdasan Emosional Sebagai Variabel Pemoderasi (Studi Empiris pada Kantor Akuntan Publik Se-Provinsi Bali). Simposium Nasional. Universitas Mataram, Lombok.

Wijayanti, Lewi, Gersontan.2012. Peran Kecerdasan Emosional dan Kecerdasan Spiritual dalam meningkatkan Kinerja Auditor. Jurnal Ilmiah Mahasiswa Akuntansi Vol. I No. 2 Maret 2012:38-42.

Website :

Didownload dari: www.iapi.or.id diakses 17 Mei 2017. 